\title{
Analysis of Brand Management Application in Enterprises in Republic of Srpska
}

\author{
TERZIĆ Svetlana \\ University of East Sarajevo, Doboj, Republic of Srpska, B\&H
}

\begin{abstract}
The economy of Republic of Srpska is in state of transition with tendency of gaining membership in EU; and also with tendency of expending the market. Therefore, it is necessary to develop the economy and means of competition which bring the value to the enterprise, and are also accepted in world's market. Also, the current state of the economy of Republic of Srpska has many problems and one of them are definitely the products which are not enough prepared through marketing, as well as the ignorance of problems and strategy of brand management, which will be presented in the paper. In other words, by focusing on the brand value and favorizing the factors which determine that value, it is possible to increase the income of domestic enterprises.
\end{abstract}

Keywords: brand, branding, nonmaterial property, enterprise, buyers

\section{Introduction}

Investment in brand builds a longterm relationship between the enterprises and buyers and therefore enables the transfer from which all participants in cooperation have benefits: the enterprise, buyers and other stakeholders (stockholders, investors, social community, law, local community and country members). Marketing concept of a brand, in other words, its value at the market has become interesting to marketing and financial experts in $80 \mathrm{~s}$ at 20th century. Until then, the politics of products was governed through communication and presentation. So, the brand management should be included in creating its longterm work strategy. Brand has a lot of properties which are important for success of enterprise in the market. Also, it has an important role enhancing the special elements of products or services and therefore decreases the risk while buying the products. The most important brand property should be the guarantee of constant quality which is recognizable in the market. So, the brand management has much greater meaning than just labeling the product, property and origin. First of all, brand is nonmaterial good and the key factor that can show the very essence of an enterprise, and it can be used to show how successful the enterprise is. If we perform an analysis of a successful brand, through which we can do an analysis of total strategic brand options (line expansion, brand expansion, option of multiple brands, brands in common and options of giving new names to the new product categories) (Milisavljevic, Maricic, \& Gligorijevic, 2001) and of marketing mix (product, price, promotion, and distribution). All this is done in order to achieve the benefits for an enterprise and other groups of interest and therefore to increase the efficiency of marketing business. In current market conditions in Republic of Srpska,

TERZIĆ Svetlana, Ph.D., assistant professor, University of East Sarajevo, Doboj, Republic of Srpska, B\&H.

Correspondence concerning this article should be addressed to TERZIĆ Svetlana, Faculty of Transport and Traffic Engineering Doboj, 74000 Doboj, Republic of Srpska, B\&H. 
marketing managers weren't able to realize the importance of brand and investment in mentioned nonmaterial mean, in aim of improvement of total profit of domestic enterprises.

The aim of this research paper is to establish the problems that occur during the brand value measurement and assumptions which have to be satisfied through achievement of wanted results in order to enable successful brand management. The paper will show that application of marketing-concept, which has its foundation in brand value, creates the possibility for its wider implementation in domestic enterprises. The brand value enables wider investment in brand and therefore the final effect, brought by brand management, is being achieved and this is the increase in total value of an enterprise which owns the brand. Therefore, it can be concluded that brand research is important because brand, as nonmaterial property of an enterprise, influences the business development of an enterprise which owns the brand. It is also an efficient strategic mean for creating the competition advance in business of enterprises in Republic of Srpska. Also, based on its value (which will present the value of world brands in paper) creates opportunities for more efficient and more effective business in marketing - sector of enterprise. It is also important to mention that brand, as marketing category, helps establishing the business according to the market rules on one hand, and on the other hand it creates possibilities for satisfying needs of all stakeholders in an enterprise.

\section{Research Methods}

The task of research is based on analysis of brand management application (and its value) in different organization forms of enterprises in Republic of Srpska. The aim of research in this paper is to establish which problems during brand management and assumptions have to be satisfied to achieve wanted results in order to enable qualitative brand management. The application of marketing-concept, which is based on brand management (and its value) possibilities for wider implementation of this concept in domestic enterprises are created. Also, possibilities for larger brand investment are created. In this way, the final effect which branding brings, is achieved, and this is the increase of value of enterprise which owns the brand. The research is performed in period between June and November 2013 at certain place in Republic of Srpska. The research has been conducted by method where inquiry in use combined the direct questioning in sample units and sending the inquiry by electronic media (internet) at the addresses of enterprises where inquiry was conducted. For determination of sample units, the secondary data from different public data bases (Chamber of Economy of the city Doboj, Chamber of Economy of the city Banja Luka, Chamber of Economy of East Sarajevo, Chamber of Economy of Bijeljina, as well as the agencies for development of small and medium enterprises in named cities) were used. The sample was defined as intentional because, for realization of the inquiry from already mentioned databases in total of 170 enterprises from area of municipalities Banja Luka, Doboj, East Sarajevo and Bijeljina, for which the author of this paper estimated to equally belong to the sector of production, service and trade enterprises, were chosen. The inquiry consists of 22 questions which are partially dichotomy (with offered answers "yes" and "no") and partially with more offered answers. Lower number of questions in inquiry is open typ. The inquiry was filled only by directors (managers) in marketing sector of enterprise or in lack of mentioned sector the directors of commercial or financial-accounting sector. Within the chosen method of inquiry and technic of direct interview with in advance formulated inquiry with 170 enterprises which took part in the research, the answer was obtained from 159 managers and thus the efficiency of the inquiry was estimated to be between $85 \%$ and $95 \%$. Also, obtained data can be analyzed with aim of determining the results of investigation. Regarding the type of enterprises and distribution structure where the inquiry was conducted, 
the results are followings: (1) Banja Luka, total of 60 enterprises (from which: 12 production, 23 service, and 25 trade); (2) Doboj, total of 47 enterprises (from which: 9 production, 20 service, and 18 trade); (3) East Sarajevo, total of 37 enterprises (from which: 8 production, 19 service, and 10 trade); (4) Bijeljina, total of 15 enterprises (from which: 5 production, 4 service, and 6 trade). Regarding the length of period in which these enterprises make business, in other words the life period of enterprises, to the category of 10 years belong 53 enterprises or $37.11 \%$, to the category between 10 and 20 years belong 53 enterprises or $33.33 \%$, to the category between 20 and 30 years belong 35 enterprises or $22.01 \%$, and to the category above 30 years belong 12 enterprises or $7.55 \%$.

\section{Results of Research and Discussion}

When it comes to the number of employees as parameters for determination of the size of sample of included enterprises the obtained results are following: 33 of enterprises or $20.75 \%$ belong to the sector of micro-enterprises, 73 or $45.91 \%$ of enterprises belong to the sector of small enterprises, 46 or $28.93 \%$ of enterprises belong to the sector of medium enterprises and only 7 or $4.40 \%$ of enterprises are one of the large enterprises. According to the data of the Agency for Statistics of Bosnia and Herzegovina for the year 2012 (data refer to the Federation of Bosnia and Herzegovina, Republic of Srpska and the District of Brcko) observing the enterprises, based on the criteria "number of employees" are obtained the following data: $38.5 \%$ of surveyed enterprises work in the sector which belongs to the large enterprises, $29.5 \%$ of them work in sector which belongs to the medium enterprises, $20.8 \%$ of them work in sector which belongs to the small and micro enterprises (Source: Agency for Statistics Press, 2013. Http: www.bhas.ba/saopštenje/2013.pdf).

Taking the annual income of enterprises as a criterion of business of enterprise into account, the situation is the following: from a total of 159 surveyed enterprises, 124 of them or $77.97 \%$ belong to the category of micro or small enterprises, with 57 or $35.85 \%$ of them stating that they achieved annual income up to $1,000,000$ $\mathrm{KM}$, then 67 or $42.14 \%$ of managers of companies stated that this income amount of $1,000,000 \mathrm{KM}$ to 10 million KM and 35 or $22.01 \%$ of enterprises are medium-sized enterprises with annual income of 10,000,000 KM up to 50,000,000 KM. According to data of the Agency for Statistics of Bosnia and Herzegovina, looking at the size of the company according to the criteria of "high revenue" in 2012, the results were following: micro enterprises in total income accounted for $20.9 \%$, small enterprises accounted for $22.9 \%$, medium accounted for 23.6\%, while the share of large enterprises is 32.6\% (Source: Agency for Statistics Press, 2013. Http: www.bhas.ba/saopštenje/2013.pdf/accessed 01.09.2015).

Otherwise, SMEs are important for the development, not only the private sector, but, in general for economic development of the country. In the European Union today operates with more than 23 million of small and medium enterprises and they only account for $99 \%$ of the total number of enterprises. Based on the global index innovation which is important, not only for the company, but also for the country and the population in 2012. Bosnia and Herzegovina are ranked at 88 place, and in 2013 at 87 place, and it is still a devastating data (http: www.aik.invest.hr/konkurentnost/mjerenje konkurentnosti / accessed 03.09.2015).

When it comes to the legal statute, or registered activity of enterprises in the sample, the classification is next: 34 enterprises $(21.38 \%)$ deal with production, trade and service sector, 42 enterprises $(26.42 \%)$ are engaged in the service sector, 26 enterprises $(16.35 \%)$ belong to the sphere of production and trade, 33 enterprises (20.75\%) deal exclusively with trade and 24 enterprises $(15.09 \%)$ were registered as legal entities for service and trade activities. Indebtedness for branding in the organizational structure or, put in another way, 
in which organizational unit are being performed activities of branding in the surveyed companies (or which organizational units according to the respondents of marketing managers should be involved in such activities): with the commitment to organizational unit it is characteristic that the 38 or $23.90 \%$ of the respondents in enterprises have put an accent on the top management, 58 or $36.48 \%$ on the marketing sector, while 18 or $11.32 \%$ of respondents believe that the activities of branding should perform combined in different organizational units, 45 or $23.8 \%$ of the respondents answered that in general there is no necessity for the implementation of branding in their companies. Previous data that $23.8 \%$ of respondents stated that there is no branding activity in their companies should not be a surprise, because in the surveyed enterprises the phenomenon that there is no marketing sector in the organizational structure (thus no orientation to marketing approach) is present. In such enterprises marketing activities are mainly based on commercial-sale activities. Consequently, based on empirical research for this study it was found that many enterprises (public and private), in order to save and reduce total operating costs, do not have developed marketing sector, they even do not have branding experts in the organizational structure. The experiences from developed economy market are completely different corporations such as Canada Dry and Colgate-Palmolive (Kotler \& Armstrong, 2004), have established the position of manager brand value. Hewlett-Packard has shifted this responsibility to the executive director whose task is to monitor the impact of activities in the framework of their business with business market and final customer market to the total value of the corporate brand. Mentioned position in the organizational structure of domestic enterprises is possible if top managers have a wide range of knowledge in the field of marketing and branding, what in domestic law and practice is not the case. This position, in the organizational structure of domestic enterprises, is justified in the context of the introduction of the position of marketing manager with knowledge and experience in the field of branding. An expert at the specified position in the organizational structure of the company would be responsible for the market success of the company, branding, brand value, marketing performance and contribution of brand to the overall business success of the company. The manager of brand value would be responsible for building and maintaining image, associations and quality in the portfolio to avoid activities that could potentially increase the value of individual brand in the short term, but at the same time could reduce its total value in the portfolio. In this research were observed different attitudes and classification of brand management activities (e.g. what they imply) according to the following structure: 64 marketing-managers or $40.25 \%$ of respondents believe that the brand management activities, which include products and services, have added value and the possibility of determining the premium prices; 52 managers or $32.70 \%$ of respondents believe that the brand management activities imply that products and services have value and a guaranteed market success; 25 managers or $15.72 \%$ of respondents claim that the activities imply that products and services can create a distinctive brand image and attract customers; then, 18 managers or $11.32 \%$ of respondents considered that the mentioned activities imply that products and services have characteristics of identity. The modern brand management involves complex and long-term activities aimed at creating value and positioning of the brand. In fact, in the long term, marketing managers should strive to the implementation of a brand with a good reputation, market position, market recognition and high specific value. Identity characteristics (name, logo, slogan, color, packaging, design, etc.) are, still, of secondary importance in relation to all of these elements, but they are, still, the initial phase of the strategic brand management.

In the new economy and a post-capitalist society, the value is created by intangible asset. Old economy, based on tangible asset, turned out to be outdated in the modern economic environment. The new economy 
based on brands, patents, relationships with employees, customers, suppliers, intellectual capital can provide growth of enterprise. When we talk about the influence of intangible asset on the growth and development of enterprise; 74 or $46.54 \%$ of respondents considered that intangible asset affects the growth and development of enterprise; 38 or $23.90 \%$ of respondents claimed that it mainly, but not completely, affects the growth and development of enterprise; 35 or $22.01 \%$ of them think that it partly affects; 12 or $7.55 \%$ of respondents argue that intangible asset does not affect the growth and development of enterprises.

The influence of intangible asset on the growth and development of enterprise

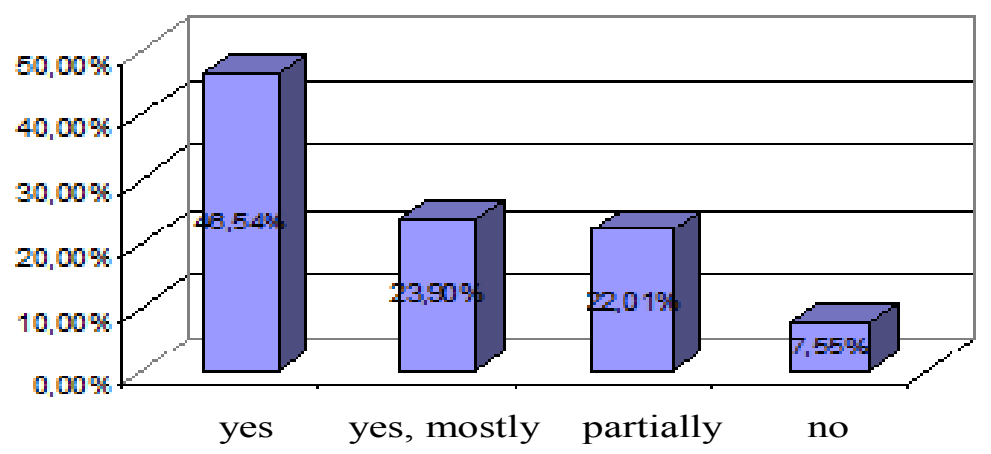

Figure 1. The influence of intangible asset on the growth and development of enterprise.

The following Figure 2 shows the classification of resources of intangible assets that has the impact on the profitable business of the company.

The types of intangible asset

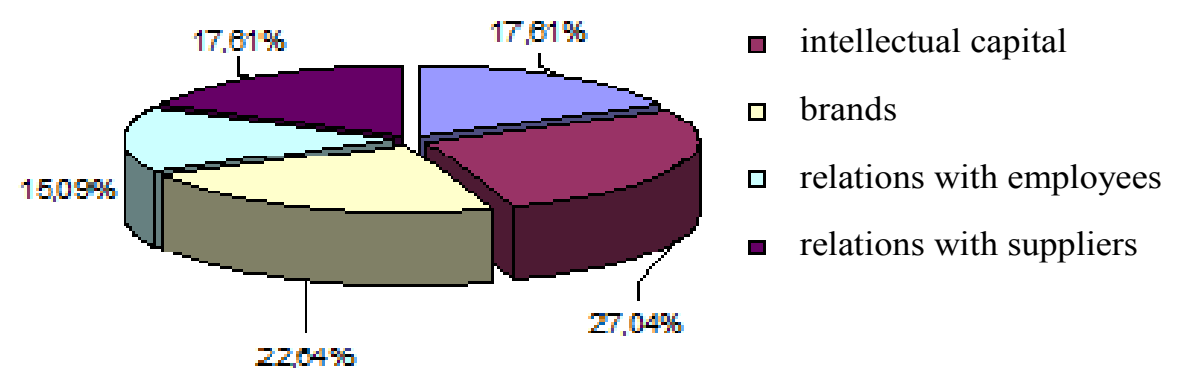

Figure 2. The types of intangible asset.

The previous chart shows the types of intangible assets which are mostly related to profitable business of enterprises; 43 or $27.04 \%$ of respondents answered that it is intellectual capital; 36 or $22.64 \%$ of them think that those are brands; 28 or $17.61 \%$ of respondents believe that those are patents, licenses, franchises, and relations with suppliers; 24 or $15.09 \%$ of respondents said that relations with employees are most important intangible asset for profitable business of enterprises.

Intellectual capital is also a means of intangible assets of enterprises that can provide a competitive advantage to them. However, like other means of intangible assets in local conditions, unlike the developed western countries, it has a different level of development and treatment. Of course, in developed countries, great attention is paid to intangible assets as "new" sources of competitive advantage. The example for this is the treatment of intellectual capital in Sweden. Specifically, profesor Leif Edvinsson believes that "intellectual 
capital is crucial for the success of modern knowledge-intensive enterprises". He became the first director of intellectual capital in the world in 1991, in the Swedish insurance company named Skandia. He developed a model of managing of intellectual capital in the company in 1995. Since then Skandia (as well as many other enterprises in the world) in their annual financial statements published a special supplement which refers to the condition of intellectual capital in the company in ways in which this hidden value is used to create additional value. It is interesting that, based on the presentation of carrying amount and market values of five largest companies in the world, at Mar. 15th, 2002. The value of intellectual capital in them was also shown, according to the following structure: (1) General Electric, the value of intellectual capital was $86.3 \%$ of total market value; (2) Microsoft, the value of intellectual capital was $85.7 \%$ of total market value; (3) Exxon Mobil-the value of intellectual capital was $75.3 \%$ of total market value; (4) Wal Mart Stons-the value of intellectual capital was $87.3 \%$ of total market value; (5) Pfizer - the value of intellectual capital was $92.7 \%$ of total market value. In five Slovenian companies the structure of the value of intellectual capital at the date Mar. 31st, 2005, was: (1) Gorenje-the value of intellectual capital was $20.9 \%$ of total market value; (2) Krka - the value of intellectual capital was $67.1 \%$ of total market value; (3) Mercator - the value of intellectual capital was $34.3 \%$ of total market value; (4) Petrol - the value of intellectual capital was $69.2 \%$ of total market value; (5) Work-the value of intellectual capital was $42.9 \%$ of total market value. From previous indicators, it is obvious that intellectual capital occupies a significant part of the value in the modern and developed enterprises: it accounts for about $70 \%$ and more of share in developed enterprises, and the enterprises of former Yugoslavia, in particular in Slovenia it is $20 \%-40 \%$ share of the market value of the company which is a valid indicator for the development (Terzic, 2012).

Having in mind that franchising is, as a specific business model (as well as branding), in large expansion in the developed countries, this mentioned theme will be analyzed in short. Franchise enterprises, as well as developed the brand-corporations employ large numbers of workers (for example in the United States is about 11 million employees in the franchise enterprises) as opposed to business in domestic conditions in which business model based on franchising and branding is not present enough, primarily because of the lack of knowledge in these business models. As defined by the International Franchise Association (IFA), franchise is "The contractual relationship between the franchisor and franchisee in which the franchisor offers or is obligated to keep the continuing interest in the business of franchisee in areas such as: know-how and training". While the recipient is obliged to operate under a joint company, the external appearance or method that belongs to the donor or he controls it, as well as to invest the base investment capital in the business from its own sources (Stefanovic \& Stankovic, 2013). Otherwise, in the international practice are present two types of franchising arrangement (Rakita, 2005): (1) International franchising of business format (e.g. McDonalds, KFC, Intercontinental); (2) International franchising of products (e.g. Coca-Cola). In applying of the franchise distribution model, internationally-oriented companies are motivated by three key factors: the possibility of market growth and expansion, profit without big direct investment, the desire to create an image of an internationally known company. The ranking of franchising companies by value and sectors in 2015 are as follows: (1) Hapton by Hilton (hotels); (2) Anytime Fitness (fitness clubs); (3) Subway (sandwiches and salads); (4) Jack in the Box (restaurants fast food); (5) Supercuts (hairdressers); (6) Jimmy John Gourmet Sandwiches with (sandwiches); (7) Servpo (insurance, restoration, and cleaning); (8) Denny's Inc. (family restaurant); (9) Pizza Hut, Inc. (American restaurant chain for the manufacture of pizzas); (10) Dunkin Donuts (coffee, donuts, and bakery products) (Janjušić, 2014). 


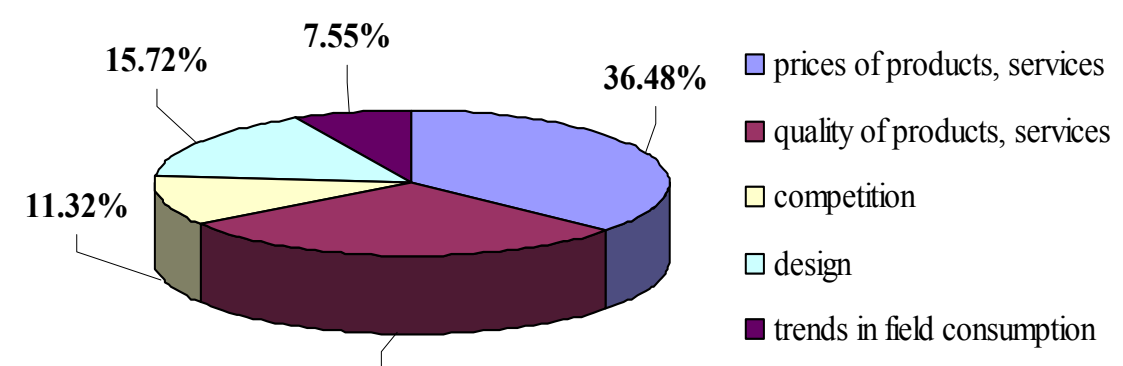

$\mathbf{2 8 . 9 3 \%}$

Figure 3. The factors of brand positioning factors in the market.

The key factors in positioning (Kancir, 2010) of the brand in the market are: (1) 58 or $36.48 \%$ of the respondents claim that it is the price of products, services; (2) the quality of products, services, considered by 46 or $28.93 \%$ of the respondents; (3) 18 or $15.72 \%$ of the respondents claim that it is the design; (4) 18 or $11.32 \%$ of the respondents claim that it is the competition; (5) trends in the field consumption, considered by 12 or $7.55 \%$ of the respondents.

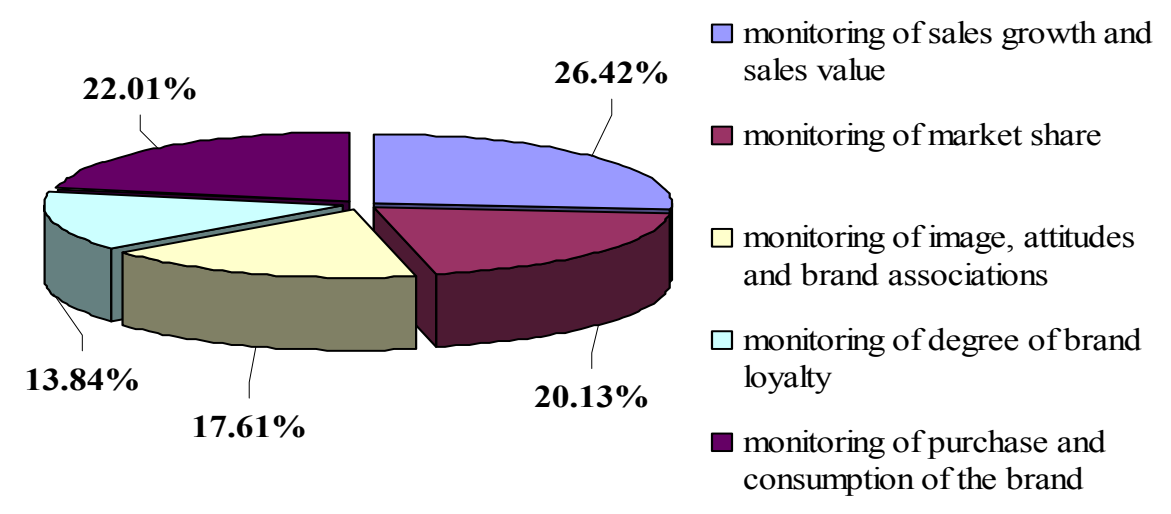

Figure 4. Types of brand monitoring.

Regarding the categorization of indicator contribution of brand to the performance of enterprises, the answers are as follows: by monitoring the growth of sales and the sales value, 42 or $26.42 \%$ of the respondents, by monitoring the purchase and consumption of the brand, 35 or $22.01 \%$, by monitoring a market share, 32 or $20.13 \%$, by monitoring image, attitudes and brand associations, 28 or $17.61 \%$ of respondents and by monitoring the degree of brand loyalty, 22 or $13.84 \%$ of respondents.

Regarding the methodology of brand value measuring (Krstic \& Popovic, 2011), only 12 or $7.55 \%$ of respondents answered affirmatively, e.g. that they are known about the methodology of measuring of brand value; 67 or $42.14 \%$ of those surveyed are partially known about the methodology of brand value measuring; 80 or $50.31 \%$ of respondents responded negatively, e.g. they are not familiar with the methodology of brand value measuring. Market brand value is that intangible dimension that indicates the ratio between the brand and the consumer. By knowing the brand and consumer relationships, the brand can be properly managed - the brand value can be developed, protected and directed in the future. In the marketing literature, market brand value is a concept which was introduced in eighties of the twentieth century. During the nineties, this subject has attracted considerable attention not just scientists, but also a great amount of attention in marketing practice, 
which served for a number of published papers and books based on this subject. Significant research in this area was conducted: Aaker and Keller (1990), Aaker (1991), Keller and Aaker (1992), Aaker and Biel (1993), Keller (1993), Simon and Sullivan (1993), Aaker (1996), Agarwal and Rao (1996), Kapferer (2001), and Keller (1998). The attention of the market value of the brand was also active in the future years, for example; Yoo and Lee (2000), Aaker and Joachimsthaler (2002), Dillon et al (2001), Keller (2001, 2003), Yoo and Donthn (2001) and Moore et al. (2002), Reich (2005), and others. Calculative brand value is determined by terms of companies and interest groups, in a way that brand value will be expressed by monetary indicators as parts of the value or financial benchmarks of companies (Krstic \& Popovic, 2011). Value estimation could be also done with measuring of difference between achieved volume of sale brand and volume of sale product with the same performance and which is not the brand (Tihi \& Radjenovic, 2008). Evaluation of brand from this aspect is especially important in the case of business combinations which involve enterprise that owns the brand. Adequate methodology for evaluation of the brand should imply the numerous quantitative and qualitative, e.g. financial and non-financial criteria. Given the above, it is necessary to make an approach that entirely determines the real value of the brand. Now the issue of how to display the brand value in the financial statements of the enterprises is very popular. Knowing the actual value of the brand which is monetarily expressed, it would be easier for managers to that predict future growth and development. Authors who have studied the research of this aspect of brand value are: Yovovich (1998), Simon and Sullivan (1993), Aaker et al. (1995), Keller (1998), Winters (1991), Salinas and Ambler (2009), Roberts (2011), and others.

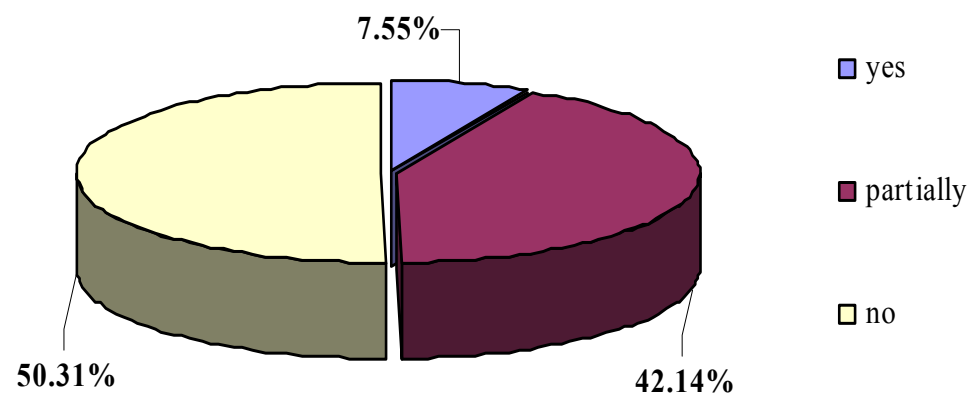

Figure 5. Knowledge about the methodology of brand value measuring.

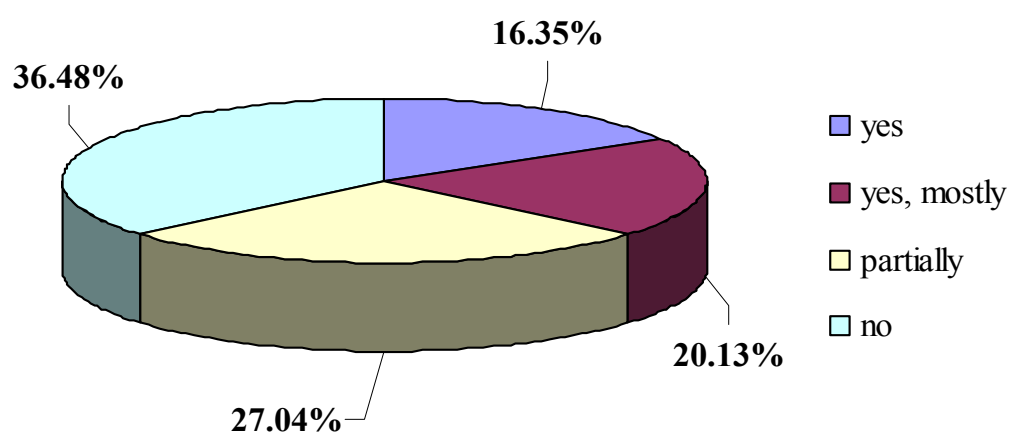

Figure 6. Knowledge about the value of world-renowned brands.

If you take the knowledge about the value of world-renowned brands into account, the classifications of the answer are: 43 or $27.04 \%$ of respondents are partially familiar with it; 58 or $36.48 \%$ of the respondents are 
not familiar with the value of world famous brands; 32 or $20.13 \%$ of the respondents replied that they are mostly familiar, but not completely, and $16.35 \%$, or 26 respondents responded affirmatively. Values of global brands in 2015 based on the assessment by Interbrand agency (http//www.milwardbrown.com/brands/ top-100global-brands/categories, accessed11/03/2015, http:/www.interbrand.com./best-global-brands/2015./ ranking/accessed 21/10/2015.) are as follows: (1) Apple (170,275 million US dollars); (2) Google (120,314 million US dollars); (3) Coca-Cola (78,423 million US dollars); (4) Microsoft (67,670 million US dollars); (5) IBM (65,095 million US dollars); (6) Toyota (49,048 million US dollars); (7) Samsung (45,297 million US dollars); (8) General Electric (42,267 million US dollars); (9) McDonalds (39,809 million US dollars); (10) Amazon (37,948 million US dollars). According to estimates by the Millward Brown Optimor agency brand value of Apple in 2015 was 246,992 million US dollars, according to the assessment by Brand Finance agency the value of the same brand is 128,303 million US dollars.

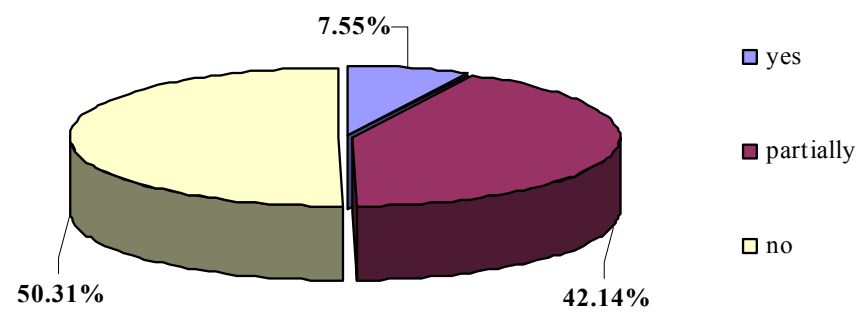

Figure 7. Influence of brand profitability.

Whether profitable brand contributes to the overall business success of the company: 53 or $33.33 \%$ of all surveyed said yes; 43 or $27.04 \%$ of them answered that it mainly contributes, but not completely; 29 or $18.24 \%$ of those surveyed responded that it contributes just partially; 34 or $21.38 \%$ of those surveyed responded negatively.

\section{Conclusion}

So, the brand, except the impact on the company and customers, also has the relative importance and impact on society, culture, politics, sports, religion and it is also significant as a category in different industries.

However, in some areas brand has a dominant and marginal importance. Brand is irrelevant for homogeneous products, respectively for those who can't differentiate, because for them the brand to the customer means nothing.

Because of the modern economic environment characterization by hyper competition on the market and a huge offer of products and choosy consumers, the focus of marketing managers should be focused on planned creation of a product worthy of attention, distinguishing characteristics and identity (name, logo, colors, design, and packaging). In domestic practice, brand value is not treated adequately, in fact it is not evaluated at all in the financial statements of the company. The concept of brand value can be viewed from the aspect of business and consumer aspect. With this in mind, in the theory and practice of marketing, there are two most advanced approaches. One is focused on determining the value of the brand in terms of enterprises, and the other is based on determining the value of the brand based on the research of consumer attitude and behavior. 
Estimation of the brand value is important when buying and selling brands, issuing license, evaluation of intangible asset, and because it is, in developed market economies, brand value included in profit of enterprise. In the accounting practice costs which are focused to explore intangible assets, despite the positive cash inflows for the company, are treated as losts in the period in which they are incurred. Only Microsoft, as the main company on the market in area of large informational technologies, thanks to its experts, was able to achieve the capitalization of its research and software development expenses. Of course, competition also takes part in benefits that exist thanks to this economic giant. It is necessary that the national accounting regulations adapt the changes. We are witnessing that many economic changes have global impact. In addition, it is important to continue the work on fixing the problem in connection with the accounting treatment of the brand. IAS 38 treats intangible asset, however, there are many unclear issues about the treatment of the brand through accounting (in the accounting sense). It is necessary to create conditions for coordinated work of experts in the field of marketing, finance and accounting in order to find common solutions for more adequate evaluation of the brand, as well as other intangible assets in domestic practice. In coming period, it is necessary to establish the conditions for branding in different activities. Opportunities for the construction and development of the brand in the domestic market exist in various industrial branches: agriculture, leather industry, footwear and textiles, wood industry, food industry, crafts, and other activities. Republic of Srpska is in the process of joining the European Union faced with the challenge and the problem of creating clearly identified products, national brands which are recognizable for wider regional and international market. Strength of the national economy in a time of market globalization and increasing competition is measured by the strength of brands which the economy has. In fact, it is a management strategy that refers to the fragmented industry branches such as: trade, services, wood processing, clothing, publishing, creative affairs and more. Fragmented industry branches are characterized by low entry barriers, lack of scale economy, the extent of local regulations and so on.

In the functioning of the economic system of the Republic of Srpska are numerous problems present: reduced economic activity, foreign product competition, unfavorable macroeconomic environment for brand investment, insufficient protection of domestic products and so on.

If in future period, some actions on removing or reducing these key problems get to be performed, the branding of the company will be more efficient and will get a completely new approach and dimension. Based on the responses of marketing managers in companies in Republic of Srpska included in the sample (of Banja Luka, Doboj, Bijeljina, and East Sarajevo), intangible assets affect the growth and development of the company (46.54\% of the respondents ) answered affirmatively.

If you take the use of resources of intangible asset that marketing managers implemented in these companies into account, based on survey indicators, the greatest importance is attached to the deep intellectual capital, nearly half of survey participants responded that from all resources of intangible asset the most commonly used one is intellect.

The marketing managers argue that, if the company has a professional staff with great knowledge, abilities and skills in marketing and brand management, it is the only way to be able to offer a successful brand to the market. Also, the assumption of creating the brand is an adequate level of marketing managers' expertise, competence and skills to build the brand as a market instrument that should be incorporated into strategic options for the company expansive business growth and it is also important for effective integration into modern trends of business. If we take marketing managers who are familiar with the methodology of brand 
value measuring into account, where only $7.54 \%$ of questioned marketing manager said yes, that they know the methodology of brand value measuring; $42.13 \%$ of the questioned are partially familiar with the methodology of brand value measuring; $50.31 \%$ of them said that they are not familiar with the methodology of brand value measuring before this research.

Regarding the impact of the profitability of brand on the overall business success of the company, $33.33 \%$ of the respondents think that profitable brand contributes to the overall business of the company, $18.23 \%$ have divided opinion and $21.38 \%$ of respondents have negative response.

Based on primary research (according to the survey of enterprises in the Republic of Srpska based on use of intangible assets in domestic companies, the brand is on fourth place), the thesis that the assumption of brand is adequate level of expertise of marketing managers, their competence and skills to build a brand that should be incorporated into strategic options of company for the expansive business growth and effective integration into modern trends of business, is confirmed.

Keeping in mind that the brand is actually the result of other segments of intellectual capital, and the fact that the research has shown that there is a high level of the correlation importance between the effects of intellectual capital and business results, we can conclude that the brand value is dominant in determination of the company's capital value, of course in the long run.

\section{References}

Aaker, D. A., \& Keller, K. L. (1990). Consumer evaluations of brand extensions. Journal of Marketing, 54(1).

Aaker, D. A. (1991). Building Strong Brands. Free Press.

Aaker, D. A., \& Biel, A. (1993). Brand equity and advertising: Advertising's role in building string brands. Lawrence Erlbaum Associaties. Inc. Mahwah, NJ.

Aaker, D. A. (1996). Building strongs, brands business \& economics. Free Press.

Aaker, D. A. (1996). Measuring brand equity across products and markets. California Management Review, 38 (3).

Aaker, D. A. (2002). Joachimsthaler, E. brand leadership. Free Press.

Agarwal, M. K., \& Rao, V. R. (1996). An empirical comparison of consumer brand measures of brand equity. Marketing letters, 7.

Dillon, W. R., Madden, T. J., Kirman, A., \& Mukkerjee, S. (2001). Understanding what's in a brand rating: A model for assessing brand and attribute effects and their relationship to brand equity. Journal of Marketing, 38.

Janjusic, D. (2014). Economic aspects of the justification of the franchise business in Serbia. Doctoral dissertation, Faculty of Business Economics, Sremska Kamenica.

Kancir, R. (2010). Marketing services, principles, and management. Belgrade.

Kapferer, J. N. (2001). Strategic brand management, Kogan Page.

Keller, K. L., \& Aaker, D. A. (1992). The effects of sequential introduction on brand extensions. Journal of Marketing Research, 29.

Keller, K. L. (1998).Understading brand equity: Answers to ten common branding questions. Exchange.

Keller, K. L. (2003). Strategic brand management. Prentice Hall.

Keller, K. L. (2001). Building customer-Based brand equity: A blueprint for creating strong brands. Marketing Management.

Kotler, P., \& Armstrong, G. (2004). Principles of marketing -4th European edition. Prentice Hall, Agency for Statistics Press.

Krstic, B., \& Popovic, A. (2011). Analysis interbrand, brand zi brand asset, methodology for evaluating brands. Marketing - Journal of Economics and Business. Belgrade.

Milisavljevic, M., Maricic, B., \& Gligorijevic, M. (2011). Fundamentals of marketing (5th ed.). Publishing Center, Faculty of Economics, Belgrade.

Moore, E. S., Wilkie, W. L., \& Lutz, R. J. (2002). Passing the torch: Intergenerational influences as a source of brand equity. Journal of Marketing, 66(2).

Peselj, B. (2006). Performance measurement, traditional and modern concepts. Faculty of Economics, Belgrade.

Reich, E. (2005). The impact of marketing mix elements on brand equity. Economic Trends and Economic Policy. Zagreb. 
Rakita, B. (2005). International marketing. Publishing Center, Faculty of Economics, Belgrade.

Roberts, K., \& Lovemarks. (2004). The future beyond brands. New York, Powerhouse Books.

Salinas, G., \& Ambler, T. (2009). A taxonomy of brand valuation methodologies: How different types of metodologies can help to answer differnt types of questions? Journal of Brand Management.

Simon, C. J., \& Sullivan M. W. (1993). The measurement and deteminant of brand equity: A financial approach. Marketing Science, 12.

Stefanovic, S., \& Stankovic, M. (2013). Comparative analysis of the development of franchising in Serbia and abroad. Marketing, 44.

Terzic, S. (2012). Intellectual capital-An indicator of value creation and competitive advantage. Faculty of Economics, East Sarajevo.

Tihi, B., \& Radjenovic, B. (2008). Marketing research. University of Business Engineering and Management, Banja Luka.

Winters, L. C. (1991). Brand equity measures: Some recent advances. Marketing Research, 3.

Yoo, B., \& Lee, S. (2000). An examination of selected marketing mix elements and brand equity. Journal of the Academy of Marketing Science, 28(20).

You, B., \& Donthn, N. (2001). Developing and validating multidimensional consumer based brand equity scale. Journal of Business Research, 52.

Yovovich, B. G. (1998). What is your brand really worth? Adwee.

http:/ aik.invest.hr/konkurentnost/mjerenjekonkurentnosti/

http:/www. enterprreneur.com/frncfises/rankings/

http:/www. interbrand.com/brands/rankings

http:/www. milwardbrown.com/brandz/top-global-brands/categories/

http:/www.brandfinance.com/brand-finance-global 500/

http:/www.bhas.ba/saopštenje 2013.pdf/ 